\title{
Isolation and characterization of exopolysaccharide-producing Weissella cibaria JNU29 and its application for production of Korean rice cake 'Sulgidduk'
}

\author{
Su-Hyun Kim ${ }^{1}$, Seung-Hee Nam², Seung-Jin Yoo $^{3}$, Kwang-Yeol Yang ${ }^{1 *}$ \\ ${ }^{1}$ Department of Applied Biology, College of Agriculture and Life Science, Chonnam National University, \\ Gwangju 61186, Korea \\ ${ }^{2}$ Institute of Agricultural Science and Technology, Chonnam National University, Gwangju 61186, Korea \\ ${ }^{3}$ Chang-eok Co., Ltd., Gwangju 61238, Korea
}

\section{세포외 다당류를 생성하는 유산균 Weissella cibaria JNU29의 분리 및 특성과 이를 이용한 한국전통 설기떡 제조

\author{
김수현 ${ }^{1} \cdot$ 남승희 $^{2} \cdot$ 유승진 $^{3} \cdot$ 양광열 $^{1 *}$
} \\ ${ }^{1}$ 전남대학교 농업생명과학대학 응용생물학과, ${ }^{2}$ 전남대학교 농업과학기술연구소, ${ }^{3}$ (주)창억}

\begin{abstract}
Due to the nutritional value of rice cakes, there is renewed interest in this traditional Korean food, and thus various efforts have been made to improve its storage stability. In this study, lactic acid bacteria that produce exopolysaccharides (EPS) were isolated and their physiochemical properties were analyzed. The bacteria were used to produce 'Sulgidduk' (a Korean rice cake) with improved storage stability. Among the 107 strains isolated from traditional fermented foods, only five strains were confirmed to produce EPS in MRS media with $10 \%$ sucrose. Two of these strains were identified as members of the genus Weissella and three were identified as the Bacillus genus via sequence analysis of 16S rDNA. Among the five strains, the strain Weissella cibaria JNU29 was selected for application to 'Sulgidduk', since it is food applicable, viable in artificial gastric and bile juices, and produces the highest content of EPS (16.72 g/L). TLC and HPLC analysis showed that the EPS produced by $W$. cibaria JNU29 strain was a homopolysaccharide composed of only glucose. A culture solution of the $W$. cibaria JNU29 strain was mixed with milled rice flour to prepare 'Sulgidduk'. After incubation for $48 \mathrm{~h}$, the 'Sulgidduk' showed lower hardness values than that of the control without the culture solution, and the lactic acid bacteria survived to a level of $7 \log \mathrm{CFU} / \mathrm{g}$. Thus, the W. cibaria JNU29 strain, which produces EPS, can be applied for the production of 'Sulgidduk', as it delays retrogradation and prevents mold-induced decay to improve shelf life.
\end{abstract}

Key words : Weissella cibaria, lactic acid bacteria, exopolysaccharide, Sulgidduk as Korean rice cake

서 론
떡은 한국 고유의 전통음식으로 재료나 제조방법에 따라
종류와 형태가 매우 다양하다(Choi, 2009). 최근 웰빙과 건강 에 관심이 높아지면서 떡의 영양학적 우수성이 재조명되어 떡 전문 프랜차이즈 업체가 생겨나며, 시장 영역을 점점 확대

*Corresponding author. E-mail : kyyang@jnu.ac.kr, Phone :+82-62-530-2076, Fax : +82-62-530-0207

Received 23 April 2020; Revised 22 June 2020; Accepted 25 June 2020.

Copyright (c) The Korean Society of Food Preservation.

This is an Open Access article distributed under the terms of the Creative Commons Attribution Non-Commercial License (http://creativecommons.org/licenses/by-nc/4.0) which permits unrestricted non-commercial use, distribution, and reproduction in any medium, provided the original work is properly cited. 
해 나가고 있다(Yoon과 Oh, 2014). 그러나 떡은 전분의 노화 로 인한 유통기간이 짧다는 단점과 가내수공업 제조방법에 따른 미생물 오염 등의 문제로 인해 생산부터 유통, 판매, 소 비되는 과정에서 다양한 문제점을 가지고 있다(Yoo 등, 2018). 전분의 노화란 부드러운 물성이 실온 혹은 냉장 저장 하였을 경우, 굳거나 마르는 현상을 나타내는 식품 용어로 전 분의 응고화라고 할 수 있는데, 이런 현상은 소화를 방해하고 식감을 떨어뜨려 상품성 저하의 주요 원인으로 보고되었다 (Gudmundsson, 1994). 수분함량(Zeleznak과 Hoseney, 1986), 저장조건(Park 등, 2009), 전분입자(Jankowski와 Rha, 1986; Nishita와 Bean, 1982) 등이 전분의 노화에 영향을 미치는 인 자로 잘 알려졌으며, 염(Beck 등, 2011), 지방(Zhou 등, 2008), 효소(Watanabe 등, 1991), 단백질(Chrastil, 1990), 다당류 (Kim와 Chung, 2007; Satrapai와 Suphantharika, 2007)와 같 은 식품첨가 재료 역시 노화에 밀접한 연관이 되어 있다고 알려져 있다. 따라서 떡의 노화 억제를 해결하기 위해서 떡을 제조할 때 쌀가루의 제분방법을 다르게 하거나(Kim 등, 1995), 올리고당(Son 등, 1997), 말티톨(Park 등, 2003), 녹차(Hong 등, 1999), 백작약(Sung과 Han, 2003) 등 노화를 억제시킬 수 있는 재료들을 첨가하는 노력들이 있었다. 떡에서 나타나는 전분의 노화에 의한 품질 저하는 빵에서도 문제가 되기 때문 에 특정한 빵을 제조할 때는 전분의 노화 및 미생물 오염에 의한 품질 저하를 막기 위해 천연 발효 과정을 거친 sourdough 를 이용한 제빵 기술을 이용하고 있다(Arendt 등, 2007). 유산 균과 효모를 포함한 다양한 미생물에 의해 만들어진 sourdough 를 이용하여 빵을 제조하면 빵의 질감, 노화 억제, 유해 곰팡 이의 생육 억제와 같은 다양한 효과가 있는 것으로 알려져 있다(Gobbetti, 1998; Hansen과 Schieberle, 2005; Tieking 등, 2003).

미생물이 생산하는 다당류의 종류는 세포벽의 일부로 사 용되는 세포내 다당류(intracellular polysaccharide)와 세포벽 구조를 구성하는 구조 다당류(structural polysaccharide), 그 리고 세포벽 외부에 점질 형태로 존재하는 세포외 다당류 (extracellular polysaccharide)로 구분된다(Cerning, 1990). 특 히 세포외 다당류는 세포벽의 일부로서 세포벽 주위에 형성 되는 협막(capsule)이나 세포벽 외부에 축적되는 점질 형태의 슬라임(slime) 등으로 다시 분류할 수 있는데, 이들을 총칭해 서 exopolysaccharide(EPS)라 부른다(Sutherland, 1972). 미 생물이 생산하는 EPS는 구성당 및 구조적 특성으로 인해 다 양한 물성을 지니고 있고, 자연계에서 쉽게 분해되고, 배양액 으로부터 쉽게 회수된다는 장점을 가지고 있어 상업적인 잠 재력이 높은 다당류이다(Kim와 Chung, 2007). 현재 EPS는 물성증진 효과, 유화제, 응집제, 접착제 등과 같이 식품, 농업, 화학에 이르기까지 다양한 분야에서 광범위하게 사용되어 산
업 소재로 높은 상업적 가치를 인정받고 있다(Cho 등, 2013). Bacillus licheniformis에서 분리한 EPS-1은 면역조절기능제 와 herpes simplex virus(HSV)의 복제를 약하게 하는 항바이 러스 활성제로(Arena 등, 2006), Sphingomonas paucimobilis 에 의해 생산되는 EPS인 젤란검과 Xanthomonas campestris pv. campestris에 의해 생산되는 EPS인 잔탄검은 식품의 맛 과 질감 향상을 위해 가장 다양하게 이용되는 식품첨가물로 개 발되었다(Sa-Correia 등, 2002; Palaniraj와 Jayaraman, 2011). 최근에는 EPS 생성 유산균인 Leuconostoc lactis $95 \mathrm{~A}$ 균주와 Lactobacillus curvatus 69B2 균주를 이용한 경우, EPS를 생 성하지 않는 유산균을 이용한 sourdough에 비해서 발효기간 중 유산균이 생성하는 유기산 또는 다당류 함량이 증가되어 점성 증가 및 노화 억제와 같은 빵의 품질 향상에 도움이 되었 다(Monaco 등, 2015). 또한, EPS 생성 유산균인 Streptococcus thermophilus St-Body1 균주를 이용하여 제조된 요구르트에 서 발효시간이 증가할수록 요구르트의 점도가 증가하였고 (Kang 등, 2005), S. thermophilus을 이용하여 제조된 요거트 에서 유청 분리 현상이 완화되고 점도가 증가됨을 확인하였 다(Hassan 등, 2003).

따라서 본 연구에서는 EPS가 점성 증가 및 노화 억제 향상 에 영향을 미친다는 것에 착안하여 떡 전분의 노화 억제 가능 성을 기대하며, 한국 전통 장류 및 발효식품으로부터 EPS 생 성하는 유산균인 Weissella cibaria JNU29 균주를 분리하여 그 특성을 분석하였다. 또한, W. cibaria JNU29 균주가 생성 하는 $\mathrm{EPS}$ 를 이용하여 저장성이 향상되는 설기떡을 제조함으 로써 유산균의 떡 산업 이용 가능성을 제시하고자 하였다.

\section{재료 및 방법}

\section{시료 및 균주 선발}

전통 장류 및 발효식품으로부터 유산균을 분리하기 위하 여 막걸리, 김치, 된장, 고추장, 간장 및 식초를 2017년 전남 지역 가정집에서 수집하였다. 시료 중 막걸리와 간장은 잘 흔 들어 단계적으로 희석하여 사용하였고, 김치, 된장 그리고 고 추장 시료는 $10 \mathrm{~g}$ 을 멸균 생리식염수 $(0.9 \% \mathrm{NaCl}) 40 \mathrm{~mL}$ 에 균질화 한 후 단계적으로 희석하여 사용하였다. 희석된 시료 는 유산균 분리를 위하여 MRS(MBcell, Seoul, Korea) 고체 배지에 도말하여 $37^{\circ} \mathrm{C}$ 에서 1-2일 동안 배양하여 미생물을 분 리하였다. 순수 분리된 미생물은 MRS 액체배지에 배양한 후, $20 \%$ glycerol에 현탁하고 $-80^{\circ} \mathrm{C}$ 에서 보관하여 실험에 사 용하였다.

분리된 미생물들 중에서 EPS 생성 유산균을 선발하기 위 해 MRS 고체배지에 $10 \%$ sucrose(Sigma Chemical Co., St. Louis, $\mathrm{MO}, \mathrm{USA}$ )를 첨가한 후, 각각의 분리된 균주 $20 \mu \mathrm{L}$ 를 
점적하여 $37^{\circ} \mathrm{C}$ 에서 2 일 동안 배양하여 콜로니 주위에 점질물 질을 생성하는 균주를 1 차 선발하였다. 1 차 선발된 균주를 다 시 $10 \%$ sucrose가 첨가된 MRS 액체배지에 $1 \%(\mathrm{v} / \mathrm{v})$ 접종하 여 점질물질을 생성하는 것을 육안으로 재확인한 후 exopolysaccharide(EPS) 생성 균주로 2차 선발하였다.

선발된 EPS 생성 능력이 높은 균주의 분자생물학적 동정을 위하여 genomic DNA extraction kit(Thermo Fisher Scientific, Waltham, MA, USA)를 사용하여 균주의 genomic DNA를 추출하였고, genomic DNA로부터 27F(5'-AGAGTTTGATCC TGGCTCAG-3')와 1492R(5'-GGTTACCTTGTTACGACTT-3') 프라이머를 이용하여 $\mathrm{PCR}$ 를 수행한 다음 $16 \mathrm{~S} \mathrm{rDNA}$ 유전자 단편을 확보한 후 염기서열을 분석하였다.

\section{EPS 생성 균주의 인공위액 및 인공담즙 저항성 확인}

MRS 액체배지와 $10 \%$ sucrose가 첨가된 MRS 액체배지에 서 선발된 균주를 $37^{\circ} \mathrm{C}, 16$ 시간 배양한 후, $\mathrm{OD}_{600}=1.0$ 으로 조 정하여 각각 인공위액 및 담즙액 저항성 실험에 사용하였다. 인공위액 내성 실험은 Kobayashi 등(1974)의 방법을 변형하 여 $\mathrm{HCl}(\mathrm{Sigma}$ Chemical Co.)로 $\mathrm{pH}$ 3.0으로 조정한 MRS 액 체배지에 $0.22 \mu \mathrm{m}$ membrane filter(Sartorius, Goettingen, Germany)로 여과한 1,000 unit $/ \mathrm{mL}$ pepsin(Sigma Chemical $\mathrm{Co}$.)을 첨가하여 인공위액을 제조하였다. 균주는 원심분리 $\left(5,000 \times g, 4^{\circ} \mathrm{C}, 10\right.$ 분 $)$ 하여 상등액을 제거하고, 인공위액을 상등액과 동량을 가하여 $37^{\circ} \mathrm{C}$ 에서 2 시간 동안 배양하여 생균 수를 계수하였다. 생존율(\%)은 [(실험구의 $\log$ 지수값/대조구 의 $\log$ 지수값) $\times 100$ ]으로 나타내었다. 대조구는 인공위액 대신 MRS 액체배지와 $10 \%$ sucrose가 첨가된 MRS 액체배 지를 사용하였다.

인공담즙 저항성 실험을 수행하기 위하여 MRS 액체배지 에 $0.22 \mu \mathrm{m}$ membrane filter로 여과된 $0.3 \%$ oxgall(Sigma Chemical Co.)을 첨가하여 인공담즙액을 제조하였다(Yun 등, 2013). 인공위액 처리를 거친 균주는 원심분리 $(5,000 \times g$, $4^{\circ} \mathrm{C}, 10$ 분)하여 상등액을 제거하고, 인공담즙액을 상등액과 동량을 가하여 $37^{\circ} \mathrm{C}$ 에서 24 시간 동안 배양하여 생균수를 계 수하였다. 생존율 $(\%)$ 은 [(실험구의 $\log$ 지수값/대조구의 $\log$ 지수값 $\times 100$ ]으로 나타내었다. 대조구는 인공담즙액 대신 MRS 액체배지와 $10 \%$ sucrose가 첨가된 MRS 액체배지를 사용하였다.

\section{EPS 생성 균주배양액의 특성 확인}

Sucrose를 사용하여 생성되는 당의 패턴을 확인하기 위하 여 $10 \%$ sucrose가 첨가된 $10 \mathrm{~mL}$ 의 MRS 액체배지에 균주를 $37^{\circ} \mathrm{C}$ 에서 2 일 배양 후 균주배양액을 TLC(Thin-Layer Chromatography) 스크리닝 시료로 사용하였다. TLC 판(Silica gel
60 F254 aluminium sheets, Merck, Darmstadt, Germany)에 $1 \mu \mathrm{L}$ 를 점적하여 전개용매(nitromethan:1-propanol:water=2: $5: 1.5, \mathrm{v} / \mathrm{v})$ 로 3 회 전개하였으며, 발색용매 $(0.5 \%$ naphtal, $5 \%$ $\mathrm{H}_{2} \mathrm{SO}_{4}$ )로 발색하여 $100^{\circ} \mathrm{C}$ 오븐에 구워 spot을 확인하여 다당 류 패턴을 비교하였다. Oligosaccharide의 표준물질인 isomaltooligosaccharide는 서울대학교 김도만 교수님 연구실에서 분 양 받아 사용하였으며 maltooligosaccharide(Sigma Chemical Co.)는 구매하여 사용하였다. 그리고 Saccharide의 표준물질로 써는 sucrose, glucose, fructose(Sigma Chemical Co.)를 사용 하였다. $10 \%$ sucrose가 첨가된 $200 \mathrm{~mL}$ 의 MRS 액체배지에 균주를 접종하여 $37^{\circ} \mathrm{C}$ 에서 2 일 동안 배양한 후, 점도계 (Brookfield viscometer, DV2T, Middleboro, MA, USA)를 이 용하여 균주배양액의 점도를 측정하였다. 점도는 spindle No.3을 사용하여 $25^{\circ} \mathrm{C}$ 에서 $20 \mathrm{rpm}$ 조건에서 측정하였다.

\section{EPS 분리 및 정량}

선발된 균주에서 생성된 $\mathrm{EPS}$ 를 분리 및 정량하기 위하여 $10 \%$ sucrose가 첨가된 $200 \mathrm{~mL}$ 의 MRS 액체배지에서 2 일 배 양된 균주배양액을 원심분리 $\left(5,000 \times g, 4^{\circ} \mathrm{C}, 10\right.$ 분 $)$ 하여 배양 된 상등액을 회수하고, 2 배의 냉각된 $95 \%$ 에탄올(Merck)을 서서히 가해 $4^{\circ} \mathrm{C}$ 에서 16 시간 침전하였다. 침전물은 원심분리 하여 회수하고, 남은 에탄올을 건조시킨 후 동결건조하였다. 동결건조된 시료에 $4 \%$ trichloloacetic acid(Sigma Chemical $\mathrm{Co}$.)를 $4{ }^{\circ} \mathrm{C}$ 에서 2 시간 처리한 후 원심분리 $\left(8,000 \times g, 4^{\circ} \mathrm{C}, 20\right.$ 분)하여 침전된 단백질을 제거하였다. 상등액을 회수하여 $0.22 \mu \mathrm{m}$ membrane filter로 여과하여 남은 단백질을 제거하 고, 2 배의 냉각된 $95 \%$ 에탄올을 가하여 $4^{\circ} \mathrm{C}$ 에서 16 시간 동 안 침전하였다. 침전물은 원심분리 $\left(8,000 \times g, 4^{\circ} \mathrm{C}, 20\right.$ 분 $)$ 하여 상등액을 제거한 후, 남은 에탄올을 건조시킨 후 멸균수에 용 해하여 dialysis sack(MW cut off 10,000, Thermo Fisher Scientific)에 넣고 $4^{\circ} \mathrm{C}$ 에서 48 시간 동안 투석한 다음 동결건 조하였다. 생성된 EPS의 생성량은 $\mathrm{g} / \mathrm{L}$ 로 나타내었다(Lynch 등, 2014).

\section{EPS 구성당 확인}

EPS의 구성당을 확인하기 위해 TLC 및 HPLC(highperformance liquid chromatography) 분석을 수행하였다. 정 제된 EPS는 $2 \mathrm{~N}$ 황산(Sigma Chemical Co.)으로 $100^{\circ} \mathrm{C}$ 에서 3-6시간 가수분해한 후 가수분해물은 $1 \mathrm{~N} \mathrm{NaOH}$ (Sigma Chemical Co.)로 중화하고, $0.22 \mu \mathrm{m}$ membrane filter를 이용 하여 여과한 후 TLC와 HPLC 시료로 사용하였다. TLC plate 에 가수분해물 $1 \mu \mathrm{L}$ 를 점적하고, 전개용매(acetone:butanol: water $=4: 5: 2, \mathrm{v} / \mathrm{v})$ 로 2 회 전개하였다. 발색용매 $(0.5 \%$ naphtal, $5 \% \mathrm{H}_{2} \mathrm{SO}_{4}$ )로 발색하여 $100^{\circ} \mathrm{C}$ 오븐에 구워 구성당의 spot을 
확인하였다. 표준물질은 monosaccharide로써 glucose, fructose, sucrose를, oligosaccharide로써 isomaltooligosaccharide, maltooligosaccharide를 사용하였다. HPLC를 통한 구성당 분석 에는 굴절률검출기인 RID-10A(Shimadzu, Koyto, Japan)와 결합된 LC-20A HPLC(Shimadzu)를 사용하였다. 분석용 column은 SUPELCOGEL C-610H $(7.8 \times 300 \mathrm{~mm}$, SUPELCO, Bellefonte, PA, USA)을 사용하였으며, column oven의 온도 는 $40^{\circ} \mathrm{C}$ 를 유지하였다. 유속은 $0.5 \mathrm{~mL} / \mathrm{min}$ 으로 유지하였고, 이동상으로 $0.1 \%$ phosphoric acid를 사용하여 45 분간 분석을 실시하였다. 표준물질로 galactronic acid, glucose, fructose, arabinose(Sigma Chemical Co.)를 사용하였다.

\section{EPS 생성 균주를 활용한 설기떡 제조 및 경도 측정}

쌀을 충분히 세척하고 1 일 동안 수침한 다음 물을 제거한 후, 소금(Sajo, Seoul, Korea) $12 \mathrm{~g}$ 을 첨가하여 roll mill (Kyungchang, Seoul, Korea)로 1차 제분하였다. 제분한 쌀가 루에 $\mathrm{EPS}$ 가 생성된 균주배양액 $180 \mathrm{~mL}$ 를 첨가하여 충분히 섞어준 후 설탕(CJ Cheiljedang, Seoul, Korea)을 혼합하여 2 차 제분하였다. 균주배양액이 포함되어 제분된 쌀가루는 30 mesh 체(Chung gye, Seoul, Korea)에 내린 다음 20 분간 쪄서 설기떡을 제조하였고, 상온 $\left(24^{\circ} \mathrm{C}\right)$ 에 2 시간 방냉한 후 실험재 료로 사용하였다. 대조군으로는 물 $180 \mathrm{~mL}$ 를 첨가하여 제조 한 떡을 사용하였다.

제조된 설기떡은 가로 $8 \mathrm{~cm} \times$ 세로 $7 \mathrm{~cm} \times$ 높이 $3 \mathrm{~cm}$ 크기로 자른 후, 밀폐용기에 넣어 제조 1 시간과 48 시간 동안 상온에 보관한 다음 실험재료로 사용하였다. 설기떡 내에서 생존한 W. cibaria 균수와 B. subtilis 균수의 측정은 멸균 생리식염 수 $(0.9 \% \mathrm{NaCl})$ 로 일정 비율로 단계 희석하여 MRS 고체배지 에 도말하여 $37^{\circ} \mathrm{C}$ 에서 1 일 동안 배양한 후 나타난 집락의 수를 계수하여 측정하였다. 또한 경도계(Sun Rheometer Compac 100-II, Sun Scientific Co., Tokyo, Japan)를 이용하여 경도 (hardness)를 측정하였다. 측정조건은 adaptor No.25를 장착 하고 테이블 스피드는 $100 \mathrm{~mm} / \mathrm{min}$, 진입거리 $50 \%$ 로 압착 시험하였다. 설기떡 제조 2 일 후부터 7 일까지 육안으로 부패
도를 확인하였다.

\section{통계처리}

실험은 3회 반복 수행하였으며, SPSS ver 25.0(Statistical Package for the Social Science, IBM, Armonk, NY, USA)을 사용하여 분석하였다. 인공위액 및 인공담즙액 결과의 통계 적 유의성은 paired t-test를 이용하여 분석하였으며, 유의수 준 0.05 일 때 유의한 차이를 나타내는 것으로 판단하였다. 점 도 측정 및 경도 측정 결과는 일원배치분산분석(one way ANOVA)을 실시하였으며, 사후분석을 통해 유의수준 0.05 를 기준으로 덩컨의 다중범위검정(Duncan's multiple range test)으로 통계처리 하였다.

\section{결과 및 고찰}

\section{EPS 생성 균주 선발 및 동정}

EPS 생성 유산균을 선발하기 위해 한국 전통 장류 및 발효 식품으로부터 분리한 107 균주를 $10 \%$ sucrose가 첨가된 MRS 고체배지에 배양하면서 투명하게 점성을 나타내거나 불투명하면서 묽게 퍼지는 표현형을 지닌 균주들을 1차로 선 발하였다. 선발된 균주를 다시 $10 \%$ sucrose가 첨가된 MRS 액체배지에 배양하면서 점질물질을 분비하는 것을 육안으로 확인하여 점성이 강하게 생성되는 5 균주를 2 차로 선발하였 다. 막걸리에서 분리한 균주는 RW9, 김치에서 분리한 균주 는 $\mathrm{KC} 29$, 간장에서 분리한 균주은 SA224, 된장에서 분리한 균주는 SP465, 고추장에서 분리한 균주는 RP506으로 명명 하였다. 분리된 균주로부터 genomic DNA를 추출하여 $16 \mathrm{~S}$ $\mathrm{rDNA}$ 염기서열을 분석한 결과, $\mathrm{RW} 9$ 와 $\mathrm{KC} 29$ 균주는 $W$. cibaria와, SA224 균주는 B. amyloliquefaciens와, SP465 균 주는 B. stratosphericus와, RP506 균주는 B. subtilis와 각각 $99 \%$ 의 상동성을 가지는 것으로 동정되었다(Table 1). Weissella 속 유산균은 현재 Lactobacillus 속과 Leuconostoc 속 유산균 과 더불어 한국의 김치 맛을 결정하는 우점종으로 잘 알려져 있으며(Kwon 등, 2002), Bacillus 속은 김치를 비롯한 청국

Table 1. Identification of potential exopolysaccharide (EPS) producing isolates by 16S rDNA sequencing

\begin{tabular}{cccc}
\hline Stock No. & Origins & Description & Identities (\%) \\
\hline RW9 ${ }^{1)}$ & Rice wine & Weissella cibaria & 99 \\
KC29 & Kimchi & Weissella cibaria & 99 \\
SA224 & Soy sauce & Bacillus amyloliquefaciens & 99 \\
SP465 & Soybean paste & Bacillus stratosphericus & 99 \\
RP506 & Red pepper paste & Bacillus subtilis & 99 \\
\hline
\end{tabular}

\footnotetext{
${ }^{1)} \mathrm{RW}$, rice wine; $\mathrm{KC}$, kimchi; SA, soy sauce; SP, soybean paste; RP, red pepper paste
} 
장, 된장과 같은 발효식품에 서식하는 것으로 알려진 고초균으 로 항균 및 항진균 활성을 가지고 있는 균으로 보고되었다(Lee 등, 2013). 따라서 최종적으로 RW9 균주는 W. cibaria JNU9 로, $\mathrm{KC} 29$ 균주는 $W$. cibaria JNU29로, $\mathrm{SA} 224$ 균주는 $B$. amyloliquefaciens JNU224로, SP465 균주는 B. stratosphericus JNU465로, RP506 균주는 B. subtilis JNU506로 명명한 후 실험에 사용하였다.

\section{EPS 생성 균주의 in vitro 인공위액 및 인공담즙 저항성}

유산균이 살아있는 상태로 최종 목적 부위인 장내에 도달 하기 위해서는 위액과 각종 효소가 존재하는 위를 통과하여야 하며, 담즙이 존재하는 십이지장을 거쳐야 한다(Dunne 등, 2001; Saarela 등, 2000). 분리된 EPS 생성 균주의 체내 소화 관 조건에서 생존 가능성을 확인하기 위하여 인공위액과 인 공담즙액에 대한 저항성 실험을 수행하였다. 인공위액 저항 성을 측정하기 위해 MRS 액체배지와 $10 \%$ sucrose 첨가된 MRS 액체배지에서 선발균주를 먼저 배양한 다음 소화효소 인 펩신이 함유된 $\mathrm{pH} 3.0$ 조건의 $\mathrm{MRS}$ 액체배지에 각각의 균주들을 접종하여 2 시간 배양한 후 생균수를 측정하였다. 인공위액 저항성을 조사한 결과, $W$. cibaria JNU9 균주와 $W$. cibaria JNU29 균주 그리고 B. subtilis JNU506 균주는 MRS 액체배지와 비교해 볼 때 $10 \%$ sucrose 첨가된 MRS 액체배 지에서 배양하였을 때 높은 생존율을 보였다(Fig. 1). 인공위 액 조건에서 W. cibaria JNU29 균주는 MRS 액체배지에서 배양할 때는 거의 생존하지 못했으나, $10 \%$ sucrose 첨가된 MRS 액체배지에서 배양할 경우에는 $70 \%$ 의 인공위액 저항 성을 나타내었다. B. subtilis JNU506 균주 역시 10\% sucrose 첨가된 MRS 액체배지에서 배양할 경우에는 $85 \%$ 정도의 높

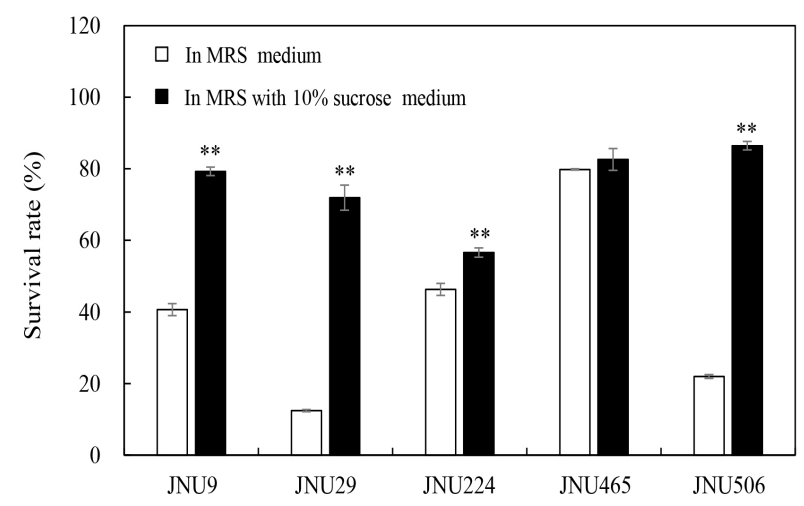

Fig. 1. Survival rates of exopolysaccharide-producing bacteria in artificial gastric juice.

Cells were cultured in MRS( $\square$ ) and MRS supplemented with $10 \%$ sucrose $(\square)$ at $37^{\circ} \mathrm{C}$ for $16 \mathrm{~h}$, subsequently incubated in artificial gastric juice for $2 \mathrm{~h}$. All values were mean $\pm \mathrm{SD}(\mathrm{n}=3) .{ }^{*} \mathrm{p}<0.05,{ }^{* * *} \mathrm{p}<0.01$, ${ }_{* *}<0.001$ compared with control treated with artificial gastric juice in MRS.
은 생존율을 보였다. 그러나 B. amyloliquefaciens JNU224 균 주와 B. stratosphericus JNU465 균주는 MRS 액체배지에 $10 \%$ sucrose 첨가 여부와 상관없이 생존율이 유지되는 것을 확인하였다. 이 결과는 전통 장류에서 분리한 Leu. citreum K6-7 균주와 Leu. mesenteroides N58-5 균주를 이용한 실험 에서 sucrose를 첨가하여 EPS가 생성된 조건의 인공위액에 서 sucrose를 첨가하지 않은 조건에 비해 생균수가 높게 나타 난 결과와 유사하였다(Yun 등, 2013).

유산균이 장내의 극한 조건에서 정상적인 기능을 수행하 려면 담즙의 농도 $(0.6 \mathrm{~g} / \mathrm{L})$ 보다 훨씬 많은 oxgallo 함유된 배 지에서 성장할 수 있는 내성을 가져야 한다(Dunne 등, 2001). 선발균주를 MRS 액체배지에서 배양한 조건에서 oxgall을 첨 가하면 모든 균주의 생존율이 $70-80 \%$ 로 oxgall 처리 전에 비 해 생균수 감소되었다(Fig. 2). 그러나 $10 \%$ sucrose 첨가된 MRS 액체배지에서 배양한 조건에서는 oxgall 처리전에 비해 모든 균주의 생균수가 증가하여 $100 \%$ 이상의 생존율을 나타 내었다. 이 결과는 Leu. kimchii GJ2 균주와 Leu. citreum C3 균주 그리고 Leu. mesenteroides $\mathrm{C} 11$ 균주를 MRS 배지에서 배양하여 EPS가 생성되지 않았을 때 인공담즙액에서 모든 균주의 생균수가 1-2 $\log \mathrm{CFU} / \mathrm{mL}$ 감소되는 현상을 보였으나, $\mathrm{EPS}$ 를 생성시킨 후 인공담즙을 처리하면 높은 담즙액 저항성 을 나타낸 결과와 일치하였다(Kim과 Chang, 2006).

Lactobacillus 속 유산균과 Leuconostoc 속 유산균이 인공 위액과 인공담즙액에서 높은 저항성을 보이는 것은 sucrose 존재 하에서 배양되는 동안 생성된 EPS가 유산균의 세포벽 주위에 보호막으로 작용한 결과이며, EPS 생성 여부가 인공 위액 및 인공담즙액에 높은 저항성을 결정하는 요인으로 보 고되었다(Ahn과 Choi, 2014; Kim과 Chang, 2006; Korakli

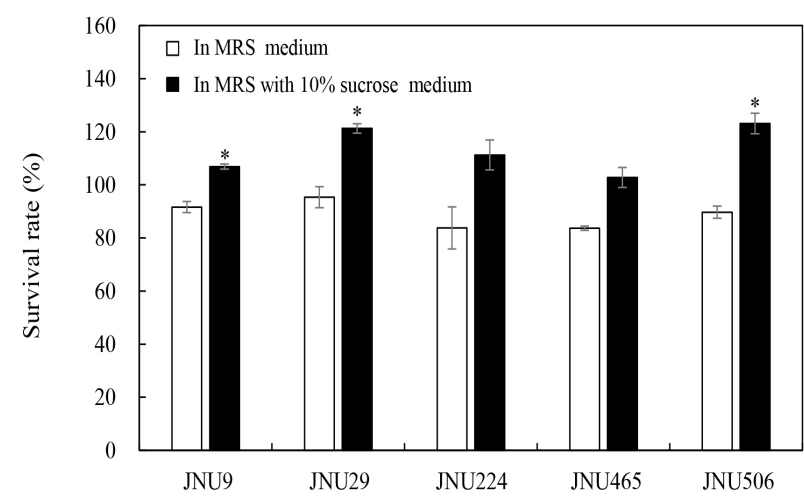

Fig. 2. Survival rates of exopolysaccharide-producing bacteria in artificial bile juice.

Cells were cultured in MRS ( $\square$ ) and MRS supplemented with $10 \%$ sucrose ( at $37^{\circ} \mathrm{C}$ for $16 \mathrm{~h}$. Cultured cells were subsequently incubated in artificial gastric juice for $2 \mathrm{~h}$ and $0.3 \%$ oxgall solution for $24 \mathrm{~h}$. All values were mean \pm SD $(n=3) . \quad{ }^{*}<0.05,{ }_{* *}^{*} p<0.01,{ }^{* * *} \mathrm{p}<0.001$ compared with control treated with $0.3 \%$ oxgall in MRS. 
등, 2002). 본 연구에서도 EPS 생성 여부가 인공위액과 인공 담즙액에 높은 저항성을 보이는 결정적인 요인이었음을 확인 할 수 있었다. 결과적으로 $10 \%$ sucrose 첨가된 MRS 액체배 지에서 EPS가 생성된 W. cibaria JNU29 균주와 B. subtilis JNU506 균주가 인공위액과 인공담즙액에 높은 저항성을 나 타냄으로써 장내 환경에서도 생존 가능한 균주로 활용하기에 적합할 것으로 평가되었다.

\section{EPS 생성 균주배양액의 특성}

유산균을 활용하여 떡을 제조하는 경우는 쌀가루와 술을 넣어 발효시켜 찐 떡인 증편이 유일하였으나, 김치에서 분리 한 $W$. koreensis $\mathrm{HO} 20$ 균주와 W. kimchii $\mathrm{HO} 22$ 균주로 발효 한 쌀가루를 이용하여 절편을 만드는 시도가 보고되었다 (Choi 등, 2013). 따라서 본 연구의 목적이 노화가 억제되는 떡을 제조하기 위해 EPS 생성 균주를 활용화 하는 것이기 때문에 먼저 설기떡에 적용할 수 있는 균주배양액 특성을 확 인하였다. 균주가 배양되는 과정에서 생성되는 당의 패턴을 확인하기 위하여 $10 \%$ sucrose가 첨가된 MRS 액체배지에 선 발된 EPS 생성 균주를 배양한 다음 TLC로 분석하였다.

모든 균주들의 균주배양액에서 점성을 나타냈으나, 다른 균주들에 비해 $W$. cibaria JNU9 균주와 $W$. cibaria JNU29 균주 그리고 B. subtilis JNU506 균주가 비교적 높은 점성을 보였다(Fig. 3A). TLC 분석 결과, $W$. cibaria JNU9 균주와 W. cibaria JNU29 균주는 첨가한 sucrose를 모두 분해하지 못하였으나 다당류 생성능이 높았고, B. amyloliquefaciens JNU224 균주, B. stratosphericus JNU465 균주는 sucrose를 거의 분해하였음에도 불구하고 다당류 생성능이 낮았다. $B$. subtilis JNU506 균주의 경우 sucrose의 분해가 모두 이루어 졌으며, 높은 다당류 생성능을 보였다(Fig. $3 \mathrm{~B})$. 결과적으로 $10 \%$ sucrose가 첨가된 MRS 액체배지에서 높은 점성을 보인 $W$. cibaria JNU9 균주와 W. cibaria JNU29 균주 그리고 $B$. subtilis JNU506 균주에서 많은 단당류 및 다당류를 생성하 는 것을 확인할 수 있었다.

점성을 보인 균주의 다당류 생성능을 비교하기 위해 $10 \%$ sucrose가 첨가된 $200 \mathrm{~mL}$ 의 MRS 액체배지에서 배양한 균주 배양액의 점도를 측정하였다. MRS 액체배지에서 배양된 조 건에서는 B. subtilis JNU506 균주의 점도가 다른 균주에 비 해 약간 높게 나타났으나, $10 \%$ sucrose가 첨가된 MRS 액체 배지에서 배양된 조건에서는 W. cibaria JNU29 균주가 가장 높은 점도를 보였다(Fig. 4). 균주 표현형상에서 비숫한 점성 을 보여 주었던 W. cibaria JNU9 균주와 W. cibaria JNU29 균주 간에도 확연한 점도 차이를 보여주었다. 그리고 $10 \%$ sucrose가 첨가된 $10 \mathrm{~mL}$ 의 MRS 액체배지에서 배양한 $B$. subtilis JNU506 균주의 배양액에서는 육안으로 확인될 정도
(A)

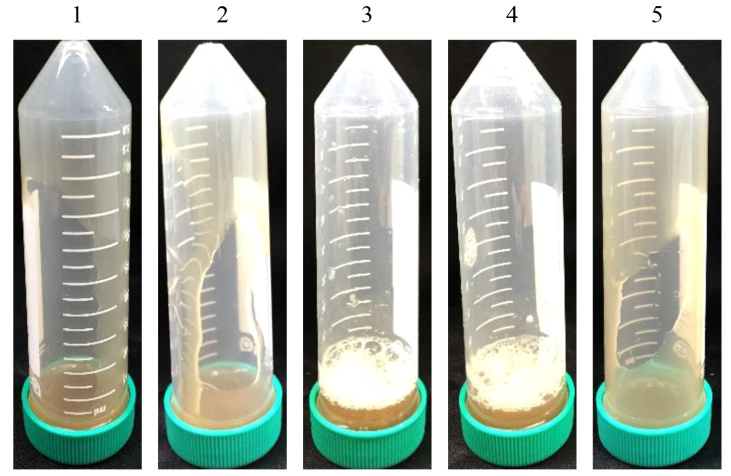

(B)

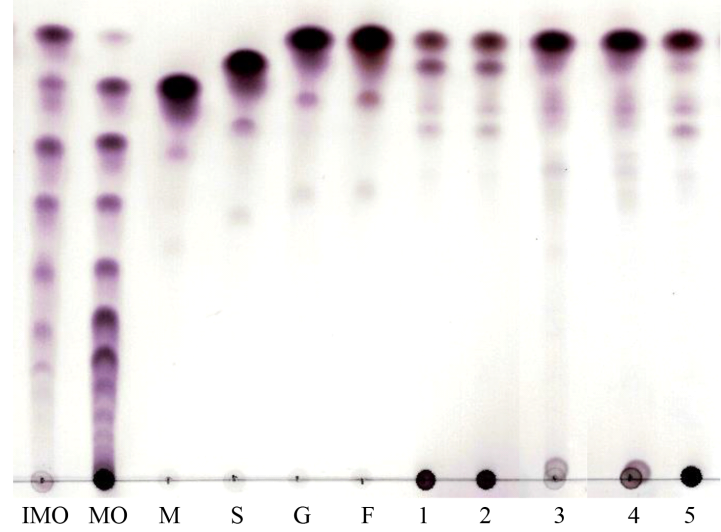

Fig. 3. Morphological aspects of exopolysaccharide production (A) and exopolysaccharide analysis by TLC (B) from 5 bacteria in MRS supplemented with $10 \%$ sucrose after 2 days of incubation at $37^{\circ} \mathrm{C}$.

(A) Sample: 1, W. cibaria JNU9; 2, W. cibaria JNU29; 3, B. amyloliquefaciens JNU224; 4, B. stratosphericus JNU465; 5, B. subtilis JNU506. (B) Standards: IMO, isomaltooligosaccharide; MO, maltooligosaccharide; M, maltose; S, sucrose; G, glucose; F, fructose.

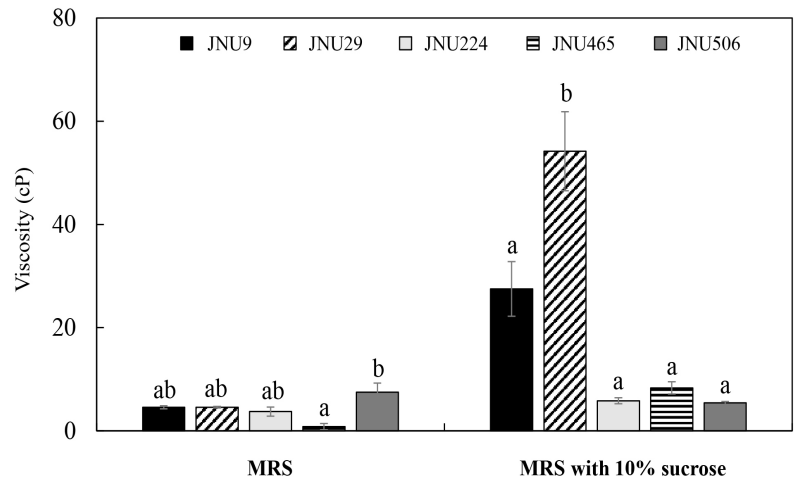

Fig. 4. Viscosity of the exopolysaccharide solution of the 5 bacteria in MRS supplemented with $10 \%$ sucrose after 2 days of incubation at $37^{\circ} \mathrm{C}$.

All values were mean $\pm \mathrm{SD}(\mathrm{n}=3)$. Means with different letters $\left({ }^{\mathrm{a}}, \mathrm{b}\right)$ above the same bar are significantly different $(\mathrm{p}<0.05)$. 
로 높은 점성을 보여 주었고, TLC 상으로도 많은 당류를 형 성하는 것을 확인하였으나, 균주배양액의 점도 측정을 위해 대 용량으로 균주를 배양한 결과는 B. amyloliquefaciens JNU224 균주와 B. stratosphericus JNU465 균주와 비슷하게 낮게 나 타났다(Fig. 4). 미생물이 생성하는 EPS는 배지의 유당함량, 탄소원이나 질소원 같은 화학적 발효조건뿐만 아니라, 온도, 산소와 $\mathrm{pH}$ 에 의한 물리적 발효조건도 생산에 차이를 보인다 고 보고되었다(De Vuyst 등, 1998, Petry 등, 2000). 특히 Razack 등(2013)에 의하면 B. subtilis 균주가 생성하는 EPS 는 $\mathrm{pH}$, 온도, 배양시간뿐만 아니라, 접종원의 농도를 $2 \%$ 에서 $1 \%$ 로 낮을 경우 EPS 생성량의 $40 \%$ 가 감소되었다고 보고하 였다. 따라서 감소된 B. subtilis JNU506 균주가 생성하는 $\mathrm{EPS}$ 의 함량은 접종원의 초기 농도와 같은 배양 환경의 차이 가 EPS 함량에 영향을 미친 것으로 생각된다.

\section{EPS 함량 및 구성당 확인}

선발된 균주의 EPS 생성 능력을 확인하기 위해 $10 \%$ sucrose 가 첨가된 $\mathrm{MRS}$ 액체배지에서 균주를 배양한 다음 $\mathrm{EPS}$ 를 정 제한 후 정량하였다. B. subtilis JNU506 균주에서 생성한 정 제된 EPS의 함량은 $8.55 \mathrm{~g} / \mathrm{L}$ 로 다른 균주들보다 유의하게 낮 은 수준이었으며, $W$. cibaria JNU29 균주는 $16.72 \mathrm{~g} / \mathrm{L}$ 로 다 른 균주들에 비해 유의하게 높은 수준으로 EPS 생성하였다 $(\mathrm{p}<0.05)$ (Table 2). 흥미롭게도 같은 종으로 동정된 W. cibaria JNU9 균주와 $W$. cibaria JNU29 균주 사이에서 EPS의 함량 은 각각 $11.58 \mathrm{~g} / \mathrm{L}$ 와 $16.72 \mathrm{~g} / \mathrm{L}$ 로 유의한 차이를 보였다. 이 와 같은 결과는 김치에서 분리한 W. cibaria CK0232, CK0235, CK0487 균주에서 서로 다른 EPS 생성 능력을 보인다는 결 과와 일치하였다(Kim과 Lee, 2013). W. cibaria JNU29 균주 에서 생성된 $\mathrm{EPS}$ 의 함량은 Leu. kimchii $\mathrm{GJ} 2$ 균주와 Leu. citreum N45-10 균주가 각각 생성했다고 보고된 $14.61 \mathrm{~g} / \mathrm{L}$ 와 $16.173 \mathrm{~g} / \mathrm{L}$ 보다 많았고(Kim과 Chang, 2006; Yun 등, 2013),

Table 2. Amounts of exopolysaccharide produced by the bacteria strains isolated from traditional fermented foods

\begin{tabular}{cc}
\hline Strains & EPS $(\mathrm{g} / \mathrm{L})$ \\
\hline W. cibaria JNU9 & $11.58 \pm 0.4^{1) \mathrm{ab} 2)}$ \\
W. cibaria JNU29 & $16.72 \pm 0.26^{\mathrm{c}}$ \\
B. amyloliquefaciens JNU224 & $8.57 \pm 0.8^{\mathrm{a}}$ \\
B. stratosphericus JNU465 & $15.38 \pm 045^{\mathrm{b}}$ \\
B. subtilis JNU506 & $8.55 \pm 0.07^{\mathrm{a}}$ \\
\hline
\end{tabular}

\footnotetext{
${ }^{1)}$ All values were mean $\pm \mathrm{SD}(\mathrm{n}=3)$.

2)a-c The same column mean significantly different as determined by Duncan's multiple range test $(\mathrm{p}<0.05)$.
}

동종인 $W$. cibaria $\mathrm{MG} 7$ 균주가 생산한 $13.7 \mathrm{~g} / \mathrm{L}$ 및 $W$. cibaria $\mathrm{F} 33$ 균주가 생산한 $16.2 \mathrm{~g} / \mathrm{L}$ 와 비교해서도 높게 나타 났다(Zannini 등, 2013). 그런 반면 B. amyloliquefaciens JNU224 균주는 상대적으로 적은 EPS 함량을 보여 주었는데, 이러한 결과는 미생물이 탄소원 종류에 따라 다당류 생성량의 차이를 보이는데 기인하다고 할 수 있다. Yilmaz 등(2012)에 의하면, Bacillus 속인 B. sphaericus 7055 균주의 경우, sucrose보다는 fructose를 첨가하여 배양하였을 경우 EPS 생 산량이 높게 증가함을 확인하였다. 그리고 본 연구를 통해 분 리한 B. stratosphericus JNU465 균주가 생성한 EPS의 함량 은 $15.38 \mathrm{~g} / \mathrm{L}$ 로 비교적 높게 나타났으나, 식품에 적용할 수 없는 미생물이기 때문에 제외하고, 다음 실험에는 W. cibaria JNU9 균주와 $W$. cibaria JNU29 균주 그리고 B. subtilis JNU506 균주를 사용하였다.

미생물이 생성하는 EPS는 구성하는 당의 종류에 따라 크게 homopolysaccharide와 heteropolysaccharide로 나뉜다. Homopolysaccharide는 한 가지 종류의 단당으로만 구성되어 있는 것을 말하며, heteropolysaccharide는 두 가지 종류 이상의 단 당으로 구성되어 있는 것을 말한다(Ruas-Madiedo 등, 2002). 선발된 균주가 생성하는 EPS의 구성당을 확인하기 위해 정 제된 EPS의 가수분해 전과 가수분해 후의 시료를 TLC로 분 석하였다. 그 결과, $W$. cibaria JNU9 균주와 $W$. cibaria JNU29 균주 그리고 B. subtilis JNU506 균주 모두에서 가수 분해 전에는 EPS 형태로 존재하다가 가수분해 후에는 glucose로 보여지는 1 개의 spot을 나타내어 glucose로만 구성 된 homopolysaccharide로 추정할 수 있었다(Fig. 5A). 균주 에 의해 생성된 EPS의 구성당을 정확하게 확인하기 위해 가 수분해물을 carbohydrate analysis column을 사용하여 HPLC 분석을 수행하여 TLC 결과와 마찬가지로 세 균주의 가수분 해 후 시료에서 모두 glucose 단일 peak만을 확인하였다(Fig. $5 \mathrm{~B})$. 점질물질을 생성하는 능력은 Weissella 속 균주의 생리 적 특성 중의 하나로 특히 W. confusa와 W. cibaria는 상당한 양의 다당류를 생성하기 때문에 높은 관심을 받아왔다(Fusco 등, 2015). W. cibaria MG1 균주의 경우, sucrose 존재 하에 glucooligosaccharides와 glucose의 선형 결합체인 dextran을 생성한다고 보고되었다(Zannini 등, 2013). 일반적으로 heteropolysaccharide가 homopolysaccharide에 비해 낮은 생 산성을 보이며 일시적으로 생산된다는 특성이 있어 산업적인 활용도는 homopolysaccharide가 높기 때문에 Leuconastoc 속에 속하는 유산균이 생성하는 homopolysaccharide인 dextran 의 경우는 의약용뿐만 아니라, 음료, 시럽, 아이스크림 등의 첨가제에도 사용되고 있다(Kim 등, 2012; Ruas- Madiedo 등, 2002). 이러한 결과로 보아 W. cibaria JNU29 균주는 많은 양의 EPS를 생산할 뿐만 아니라 Homopolysaccharide로 구성 
(A)

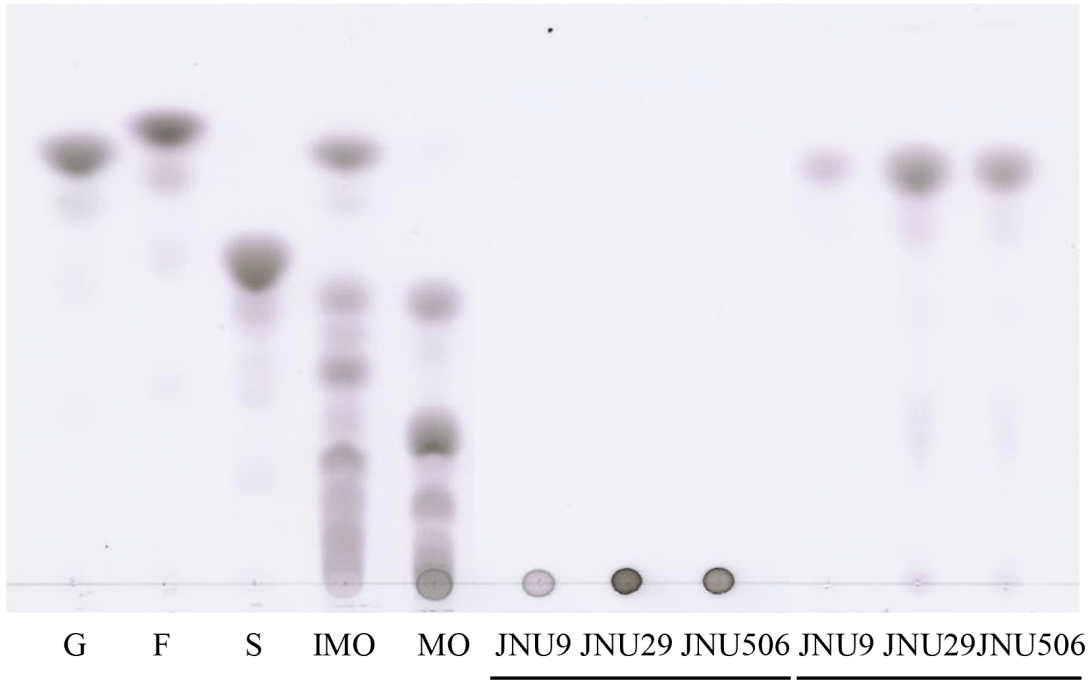

Before hydrolysis

After hydrolysis

(B)
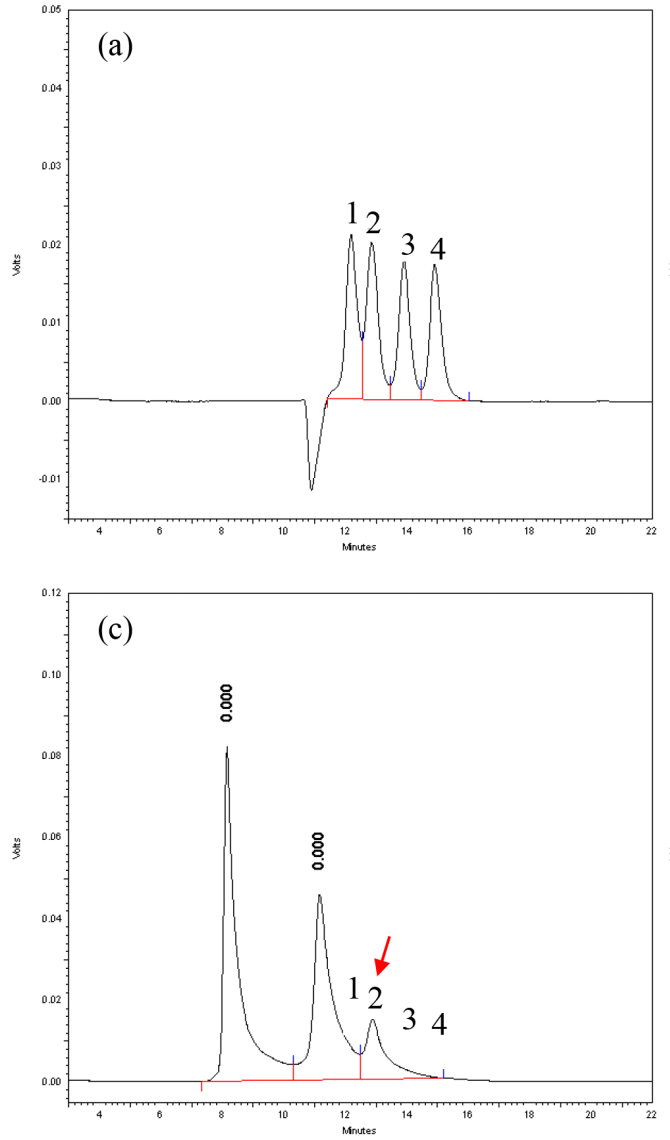

(b)

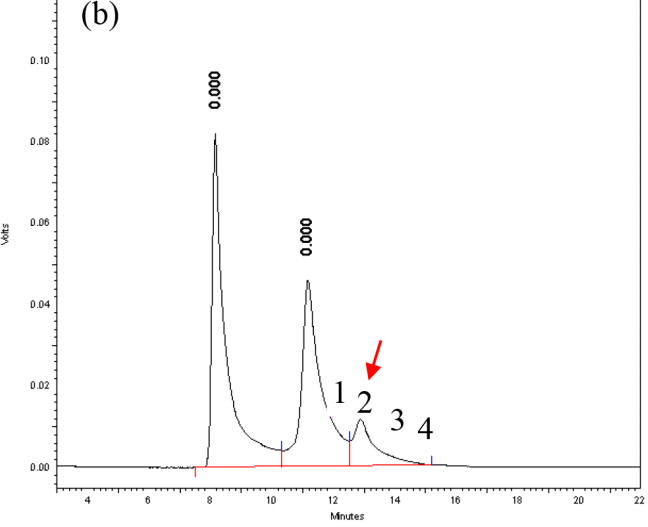

(d)

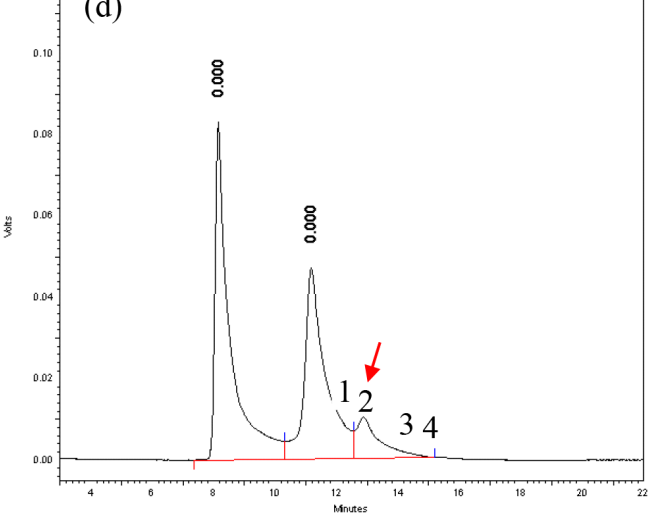

Fig. 5. TLC plate (A) and HPLC analysis (B) after acid hydrolysis of exopolysaccharide produced by $W$. cibaria JNU9, W. cibaria JNU29 and $B$. subtilis JNU506.

(A) Standards: G, glucose; F, fructose; S, sucrose; IMO, isomaltooligosaccharide; MO, maltooligosaccharide. (B) (a) Standards: 1, galactronic acid; 2, glucose; 3, fructose; 4, arabinose. (b) W. cibaria JNU9 (c) W. cibaria JNU29 (d) B. subtilis JNU506. The arrow indicates the hydrolysate of exopolysaccharide produced by bacteria strains. 
되어 있어 산업적 이용도가 높을 것으로 생각되었다.

\section{EPS 생성능 균주를 활용한 설기떡의 경도}

떡은 조리방법에 따라 찐떡, 친떡, 지진떡 그리고 삶은떡으 로 구분되는데 그 중 찐떡의 가장 기본이 되는 떡이 설기떡이 다(Yoon, 2007). 설기떡은 제분된 쌀가루를 사용하여 시루에 찐 떡으로 섞는 주재료와 부재료의 종류에 따라 다양하게 개 발이 가능한 음식이다(Cho 등, 2006). 그러나 설기떡의 주재 료인 멥쌀은 구조상 노화가 빨리 일어나 저장성과 상품성이 떨어져 품질 개선이 필요한 실정이다(Kang 등, 2010). 따라 서 본 연구에서는 한국 전통 발효식품으로부터 분리한 EPS 생성 균주 중에서 식품에 적용 가능하고 장내에서 생존도 우 수하며 EPS 생성 함량이 가장 높게 나타난 W. cibaria JNU29 균주를 선택하여 설기떡을 제조하여 그 특성을 확인하고자 하였다. 1차 제분한 쌀가루에 선택한 W. cibaria JNU29 균주 의 배양액을 혼합한 후 2차 제분한 다음 쌀가루를 이용하여 시루에 20 분간 증기로 쪄서 설기떡을 제조하였다. 제조된 설 기떡 내에 첨가한 균주의 생존 여부를 확인해 보기 위해 제조 한 다음 1 시간 방냉한 후 생존한 균주의 수와 48 시간 동안 상온에 보관한 다음 MRS 고체 배지에서 생존한 균주의 수를 각각 조사해 보았다. 그 결과, W. cibaria JNU29 균주의 배양 액을 사용하지 않은 설기떡 대조구에서는 전혀 균주가 확인 되지 않은 반면, $W$. cibaria JNU29 균주의 배양액을 사용한 설기떡에서 제조 1시간 후에는 $2 \log \mathrm{CFU} / \mathrm{g}$ 수준으로 균주 가 생존하였으며, 제조 48시간 후에는 $7 \log \mathrm{CFU} / \mathrm{g}$ 수준으로 생존하였다. 이 결과는 W. cibaria JNU29 균주가 떡의 제조 조건에서 생존 가능하므로 W. cibaria JNU29 균주의 배양액 을 혼합하여 제분한 쌀가루를 이용하여 제조된 설기떡에는 유산균이 풍부하게 함유되어 있음을 의미한다.

EPS 균주의 균주배양액으로 제조된 설기떡의 저장성에 대 한 영향을 확인하기 위해 설기떡의 경도 변화를 측정해 보았 다. 측정한 결과, 제조한 다음 1 시간 방냉한 후의 설기떡의 경도는 균주배양액을 혼합하지 않은 대조구와 균주배양액이 혼합된 시험구 간 큰 차이가 없었다. 그러나 제조한 후 48시 간이 지난 시료에서는 W. cibaria JNU29 균주로 제조된 설기 떡의 경우 대조구에 비해 경도 값이 유의하게 감소하는 경향 을 보여 저장성이 향상되었음을 확인할 수 있었다(Fig. 6A). 또한 W. cibaria JNU29 균주는 저장성 향상 효과뿐만 아니라, 곰팡이에 의한 부패에도 영향을 미쳤다. 균주배양액을 혼합 하지 않은 대조구는 제조 3 일부터 부패되기 시작하여 7일 후 에는 전체의 $1 / 4$ 정도가 부패가 되었으나, 균주배양액으로 제 조한 설기떡에서는 7일 후부터 일부에서 부패가 시작되고 있 음을 확인하였다(Fig. 6B). 이 결과는 설기떡 제조 시 $W$. cibaria 균주에 의해 생성되는 EPS가 떡의 부패를 야기하는
유해균의 생장을 억제함을 확인하였다. 기존의 연구결과에 서도 유산균이 Penicillium commune, Mucor racemosus, Galactomyces geotrichum 그리고 Yarrowia lipolytica 등과 같은 식중독을 야기하는 진균에 항균효과가 있다고 보고하였 다(Salas 등, 2019). 또한, Choi 등(2013)은 김치유산균인 $W$. koreensis $\mathrm{HO} 20$ 와 $W$. kimchii $\mathrm{HO} 22$ 로 발효한 쌀가루로 제 조된 절편에서 떡의 부패에 관여하는 곰팡이를 억제하고 노 화를 지연한다고 보고하였다.

본 연구에서는 한국 전통 장류 및 발효식품으로부터 EPS 를 생성하는 유산균 $W$. cibaria JNU29 균주를 분리하고, 그 균주배양액을 혼합하여 제분한 쌀가루를 이용하여 설기떡을 제조함으로써 저장성을 향상시킬 뿐만 아니라, 항균 효과까지 기대할 수 있었다. 결론적으로 본 연구에서 선발한 $W$. cibaria JNU29 균주가 장기 유통 가능한 떡을 제조하는데 유용한 소 재로 이용될 수 있음을 확인하였다.

\section{요 약}

최근 건강에 관심이 높아지면서 한국 고유의 전통음식인 떡의 영양학적 우수성이 재조명되면서 저장성이 약한 단점을 보완하기 위한 다양한 노력들이 시도되고 있다. 본 연구에서 는 세포외 다당류(EPS)를 생성하는 유산균을 분리하여 그 특 성을 분석하고, 이를 이용하여 저장성이 향상되는 설기떡을 제조하고자 하였다. 전통 장류 및 발효식품으로부터 분리한 107 개 균주들 중에서 $10 \%$ sucrose가 첨가된 MRS 고체 및 액체배지에서 점질물질을 형성하는 표현형을 통해 2차에 걸 쳐 $\mathrm{EPS}$ 를 생성하는 5 개 균주를 선발하였고, $16 \mathrm{~S} \mathrm{rDNA}$ 의 염 기서열 분석을 통해 Weissella 속 2개 균주와 Bacillus 속 3 개 균주로 동정하였다. 선발한 EPS 생성 5 개 균주들 중에서 설 기떡에 응용하기 위해 식품에 적용 가능하고 인공위액 및 인 공담즙액에서 생존성이 우수하고, EPS 함량이 $16.72 \mathrm{~g} / \mathrm{L}$ 로 가장 높게 나타난 $W$. cibaria JNU29 균주를 최종적으로 선 택하였다. 이 균주의 EPS는 glucose로 구성된 homopolysaccharide임을 확인하였고, 1 차 제분 쌀가루에 균주배양액을 혼합하여 2차 제분 설기떡을 제조하였다. 그 결과, 설기떡에 서 48시간 후에 유산균이 $7 \log \mathrm{CFU} / \mathrm{g}$ 수준으로 생존하였으 며, 대조구에 비해 경도 값이 감소하는 경향을 보여 저장성이 향상되었음을 확인하였다. 따라서 EPS를 생성하는 W. cibaria JNU29 균주는 저장성이 향상된 설기떡을 제조하는데 도움이 될 수 있음을 시사하였다.

\section{감사의 글}

본 연구는 농림축산식품부의 재원으로 농림식품기술기획 
(A)

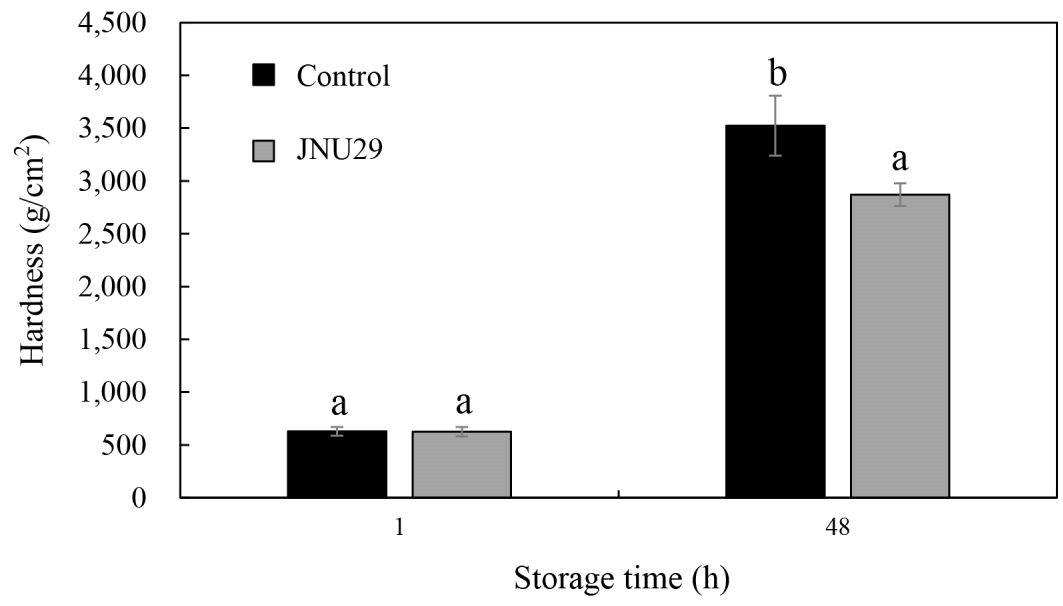

(B)

Control
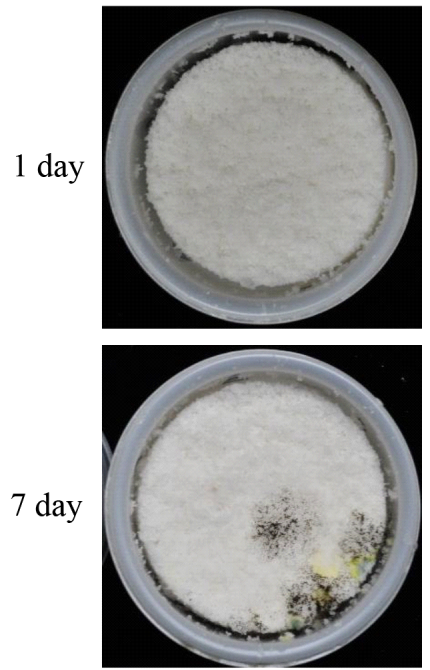

W. cibaria JNU29
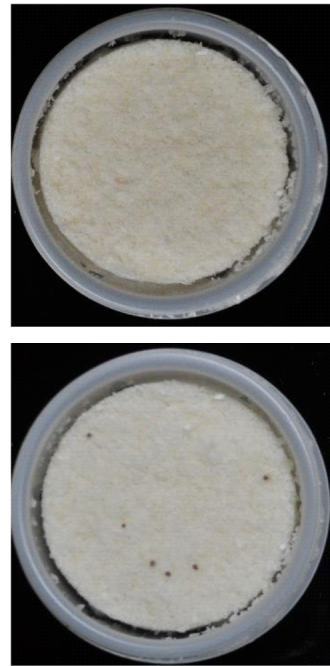

Fig. 6. Hardness (A) and mold-induced decay (B) of 'Sulgidduk' added with exopolysaccharide produced by $W$. cibaria JNU29 during storage. (A) All values were mean $\pm \mathrm{SD}(\mathrm{n}=3)$. Means with different letters $\left({ }^{\mathrm{a}, \mathrm{b}}\right)$ above the same bar are significantly different $(\mathrm{p}<0.05)$.

평가원의 고부가가치식품기술사업(PJ117075-3)과 농촌진흥 청의 유자 수출용 가공기술과 가공제품 개발(PJ013826)에 의 해 이루어진 것으로 이에 감사드립니다.

\section{Conflict of interests}

The authors declare no potential conflict of interest.

\section{ORCID}

Su-Hyun Kim

https://orcid.org/0000-0002-8684-7178
Kwang-Yeol Yang https://orcid.org/0000-0002-8040-5467

\section{References}

Ahn YJ, Choi HS. Potential probiotic properties of exopolysaccharide producing lactic acid bacteria isolated from fermented soybean product. J Korean Soc Food Sci Nutr, 43, 749-755 (2014)

Arena A, Maugeri TL, Pavone B, Iannello D, Gugliandolo C, Bisignano G. Antiviral and immunoregulatory effect of a novel exopolysaccharide from a marine thermo- 
tolerant Bacillus licheniformis. Int Immunopharmacol, 6, 8-13 (2006)

Arendt EK, Ryan LAM, Dal Bello F. Impact of sourdough on the texture of bread. Food Microbiol, 24, 165-174 (2007)

Beck M, Jekle M, Becker T. Starch re-crystallization kinetics as a function of various cations. Starch-Starke, 63,792800 (2011)

Cerning J. Exocellular polysaccharides produced by lactic acid bacteria. FEMS Microbiol Rev, 87, 113-130 (1990)

Cho EJ, Yang MO, Hwang CH, Kim WJ, Kim MJ, Lee MK. Quality characteristics of Sulgidduk added with Rubus coreanum Miquel during storage. J East Asian Soc Dietary Life, 16, 458-467 (2006)

Cho GY, Jeon IH, Han SI, Whang KS. Isolation and characteristics of exopolysaccharide producing bacteria in a ginseng root system. Korean J Microbiol, 49, 297-300 (2013)

Choi HY. Antimicrobial activity of Paeonia japonica extract and its quality characteristic effects in Sulgidduk. Korean J Food Cookery Sci, 25, 435-444 (2009)

Choi HJ, Lee HW, Yoon S. Fermentation of rice flour with Weissella koreensis $\mathrm{HO} 20$ and Weissella kimchii $\mathrm{HO} 22$ isolated from kimchi and its use in the making of jeolpyeon. Korean J Food Cookery Sci, 29, 267-274 (2013)

Chrastil J. Protein-starch interactions in rice grains. Influence of storage on oryzenin and starch. J Agric Food Chem, 38, 1804-1809 (1990)

De Vuyst L, Vanderveken F, Van de Ven S, Degeest B. Production by and isolation of exopolysaccharides from Streptococcus thermophilus grown in a milk medium and evidence for their growth-associated biosynthesis. J Appl Microbiol, 84, 1059-1068 (1998)

Dunne C, O’Mahony L, Murphy L, Thornton G, Morrissey D, O’Halloran S, Feeney M, Flynn S, Fitzgerald G, Daly C, Kiely B, O’Sullivan GC, Shanahan F, Collins JK. In vitro selection criteria for probiotic bacteria of human origin: Correlation with in vivo findings. Am J Clin Nutr, 73, 386-392 (2001)

Fusco V, Quero GM, Cho GS, Kabisch J, Meske D, Neve H, Bockelmann W, Franz CMAP. The genus Weissella: Taxonomy, ecology and biotechnological potential. Front Microbiol, 6, 1-22 (2015)
Gobbetti M. The sourdough microflora: Interactions of lactic acid bacteria and yeasts. Trends Food Sci Technol, 9, 267-274 (1998)

Gudmundsson M. Retrogradation of starch and the role of its components. Thermochim Acta, 246, 329-341 (1994)

Hansen A, Schieberle P. Generation of aroma compounds during sourdough fermentation: Applied and fundamental aspects. Trends Food Sci Technol, 16, 85-94 (2005)

Hassan AN, Ipsen R, Janzen T, Qvist KB. Microstructure and rheology of yogurt made with cultures differing only in their ability to produce exopolysaccharides. J Dairy Sci, 86, 1632-1638 (2003)

Hong HJ, Choi JH, Choi KH, Choi SW, Rhee SJ. Quality changes of Sulgiduk added green tea powder during storage. J Korean Soc Food Sci Nutr, 28, 1064-1068 (1999)

Jankowski T, Rha CK. Retrogradation of starch in cooked wheat. Starch-Starke, 38, 6-9 (1986)

Kang HJ, Baick SC, Yu JH. Studies on the properties of the stirred yogurt manufactured by exopolysaccharide producing lactic acid bacteria. Korean J Food Sci Ani Resour, 25, 84-91 (2005)

Kang HJ, Kim SH, Kum JS, Lim JK. Effect of ginseng powder on quality characteristics of instant rice cake (Baekseolgi). J Korean Soc Food Sci Nutr, 39, 435-442 (2010)

Kim YI, Kum JS, Lee SH, Lee HY. Retrogradation characteristics of Jeungpyun by different milling method of rice flour. Korean J Food Sci Technol, 27, 834-838 (1995)

Kim HJ, Chang HC. Isolation and characterization of exopolysaccharide producing lactic acid bacteria from kimchi. Korean J Microbiol Biotechnol, 34, 196-203 (2006)

Kim SS, Chung HY. Texture properties of a Korean rice cake (Karedduk) with addition of carbohydrate materials. J Korean Soc Food Sci Nutr, 36, 1205-1210 (2007)

Kim JE, Whang K, Lee SP. Physicochemical properties of dextran produced by Leuconostoc mesenteroides SM according to concentration of yeast extract and its modulation of rheological properties. Korean J Food Sci Technol, 44, 216-223 (2012)

Kim HR, Lee JH. Selection of acid-tolerant and heterofermentative lactic acid bacteria producing non-proteinaceous anti-bacterial substances for kimchi fermentation. 
Korean J Microbiol Biotechnol, 41, 119-127 (2013)

Kobayashi Y, Toyama K, Terashima T. Biological characteristics of Lactobacillus. II. Tolerance of a multiple antibiotic resistant strain, Lactobacillus casei PSR 3002, to artificial digestive fluids. Nihon Saikingaku Zasshi, 29, 691-697 (1974)

Korakli M, Ganzle MG, Vogel RF. Metabolism by bifidobacteria and lactic acid bacteria of polysaccharides from wheat and rye, and exopolysaccharides produced by Lactobacillus sanfranciscensis. J Appl Microbiol, 92, 958-965 (2002)

Lee NK, Kim SY, Choi SY, Paik HD. Probiotic Bacillus subtilis KU201 having antifungal and antimicrobial properties isolated from kimchi. Food Sci Biotechnol, 22, 1375-1379 (2013)

Lynch KM, McSweeney PLH, Arendt EK, Uniacke-Lowe T, Galle S, Coffey A. Isolation and characterisation of exopolysaccharide-producing Weissella and Lactobacillus and their application as adjunct cultures in Cheddar cheese. Int Dairy J, 34, 125-134 (2014)

Monaco RD, Torrieri E, Pepe O, Masi P, Cavella S. Effect of sourdough with exopolysaccharide (EPS)-producing lactic acid bacteria (LAB) on sensory quality of bread during shelf life. Food Bioprocess Technol, 8, 691-701 (2015)

Nishita KD, Bean MM. Grinding methods: Their impact on rice flour properties. Cereal Chem, 59, $46-49$ (1982)

Park JW, Park HJ, Song JC. Suppression effect of maltitol on retrogradation of Korean rice cake (Karedduk). J Korean Soc Food Sci Nutr, 32, 175-180 (2003)

Park EY, Baik BK, Lim ST. Influences of temperaturecycled storage on retrogradation and in vitro digestibility of waxy maize starch gel. J Cereal Sci, 50, 43-48 (2009)

Palaniraj A, Jayaraman V. Production, recovery and applications of xanthan gum by Xanthomonas campestris. J Food Eng, 106, 1-12 (2011)

Petry S, Furlan S, Crepeau MJ, Cerning J, Desmazeaud M. Factors affecting exocellular polysaccharide production by Lactobacillus delbrueckii subsp. bulgaricus grown in a chemically defined medium. Appl Environ Microbiol, 66, 3427-3431 (2000)

Razack AS, Velayutham V, Thangavelu V. Influence of various parameters on exopolysaccharide production from Bacillus subtilis. Int J ChemTech Res, 5, 2221-
2228 (2013)

Ruas-Madiedo P, Hugenholtz J, Zoon P. An overview of the functionality of exopolysaccharides produced by lactic acid bacteria. Int Dairy J, 12, 163-171 (2002)

Saarela M, Mogensen G, Fonden R, Matto J, MattilaSandholm T. Probiotic bacteria: Safety, functional and technological properties. J Biotechnol, 84, 197-215 (2000)

Salas ML, Thierry A, Lemaître M, Garric G, Harel-Oger M, Chatel M, Le S, Mounier J, Valence-Bertel F, Coton E. Potential of antifungal lactic acid bacteria combinations as bioprotective agents in pilot scale dairy products. Paper presented at ICFM Conference on Food and Airborne Fungi Challenges for Food Safety and Supply, June 3-5, Freising, Germany (2019)

Satrapai S, Suphantharika M. Influence of spent brewer's yeast $\beta$-glucan on gelatinization and retrogradation of rice starch. Carbohydr Polym, 67, 500-510 (2007)

Sa-Correia I, Fialho AM, Videira P, Moreira LM, Marques AR, Albano H. Gellan gum biosynthesis in Sphingomonas paucimobilis ATCC 31461: genes, enzymes and exopolysaccharide production engineering. J Ind Microbiol Biotechnol, 29, 170-176 (2002)

Shehata MG, El Sohaimy SA, El-Sahn MA, Youssef MM. Screening of isolated potential probiotic lactic acid bacteria for cholesterol lowering property and bile salt hydrolase activity. Ann Agric Sci, 61, 65-75 (2016)

Son HS, Park SO, Hwang HJ, Lim ST. Effect of oligosaccharide syrup addition on the retrogradation of a Korean rice cake (Karedduk). Korean J Food Sci Technol, 29, 1213-1221 (1997)

Sung JM, Han YS. Effect of Bakjakyak (Paeonia japonica) addition on the shelf-life and characteristics of rice cake and noodle. Korean J Food Culture, 18, 311-319 (2003)

Sutherland IW. Bacterial exopolysaccharides. Adv Microb Physiol, 8, 143-213 (1972)

Tieking M, Korakli M, Ehrmann MA, Ganzle MG, Vogel RF. In situ production of exopolysaccharides during sourdough fermentation by cereal and intestinal isolates of lactic acid bacteria. Appl Environ Microbiol, 69, 945-952 (2003)

Watanabe M, Arai E, Honma K, Fuke S. Improving the cooking properties of aged rice grains by pressurization and enzymatic treatment. Agric Biol Chem, 55, 27252731 (1991) 
Yilmaz M, Yuvali Celik G, Aslim B, Onbasili D. Influence of carbon sources on the production and characterization of the exopolysaccharide (EPS) by Bacillus sphaericus 7055 strain. J Polym Environ, 20, 152-156 (2012)

Yoo SJ, Chin JE, Oh SH, Ryu MJ, Hwang KT. Prediction of shelf-life of rice cake processing products for HMR foods. J Chitin Chitosan, 23, 190-198 (2018)

Yoon SJ. Quality characteristics of Sulgitteok added with lotus leaf powder. Korean J Food Cookery Sci, 23, 433-442 (2007)

Yoon SJ, Oh IS. Usage status of traditional rice cake as a meal substitute and analysis on the selection attributes affecting purchase. Korean J Culin Res, 20, 38-53 (2014)

Yun HJ, Lee YJ, Yeo SH, Park HY, Park HD, Baek SY. Isolation and characterization of exopolysaccharide producing lactic acid bacteria from Korean soy sauce and soybean paste. Korean J Microbiol Biotechnol, 41, 190-197 (2013)

Zannini E, Mauch A, Galle S, Ganzle M, Coffey A, Arendt EK, Taylor JP, Waters DM. Barley malt wort fermentation by exopolysaccharide-forming Weissella cibaria MG1 for the production of a novel beverage. J Appl Microbiol, 115, 1379-1387 (2013)

Zeleznak KJ, Hoseney RC. The role of water in the retrogradation of wheat starch gels and bread crumb. Cereal Chem, 63, 407-411 (1986)

Zhou YB, Wang DF, Zhang L, Du XF, Zhou XL. Effect of polysaccharides on gelatinization and retrogradation of wheat starch. Food Hydrocolloids, 22, 505-512 (2008) 